Vol. 5, No. 6, June, 2019

\title{
Comparative Study of Structural Behaviour for Rolled and Castellated Steel Beams with Different Strengthening Techniques
}

\author{
Shakir Mahmood Hadeed ${ }^{\mathrm{a}}$, Ahmad Jabbar Hussain Alshimmeri ${ }^{\mathrm{b}^{*}}$ \\ ${ }^{a}$ M.Sc. Student, Civil Engineering Department, Baghdad University, Baghdad, Iraq. \\ ${ }^{b}$ Assistant Professor, Civil Engineering Department, Baghdad University, Baghdad, Iraq.
}

Received 13 March 2019; Accepted 07 June 2019

\begin{abstract}
Currently, the castellated steel beams are used widely because of their useful structural applications and serviceable performance due to their good significant properties such as light weight, facility in construction, materials economize and strength. The castellated steel beam fabricated from its origin solid beam (I-beam) by cutting its web in a zigzag path and then re-joined the two halve by welding so the height of the castellated beam expanded about $50 \%$. The aim of this paper is to study the effect of castellation with and without strengthening on the structural behaviour of castellated beams and compare the results with the origin solid steel beam. Three castellated beams with deferent configuration in addition to solid beam subjected to two equal point loads at mid third of span with simple support condition were analysed numerically using finite element analysis by Abaqus software virgin (6.14.5). The results show that the load carrying capacity values of castellated steel beams that represent (second, third\& fourth) models were increased by $(39.11,105.95$ and 124.77$) \%$ respectively compared with origin solid beam due to increase beams stiffness after castellation and strengthening process, while mid-span deflection values at service load were decreased by $(36.36,9.10$ and 27.27$) \%$ respectively comparing with the origin solid steel beam due to increasing section dimensions and stiffness after castellation process and using strengthening technique respectively. Also it was seen that the maximum ultimate moment and ductility were observed in the fourth model that strengthened by high strength concrete and lacing reinforcement so they increased by $124.79 \%$ and $165.65 \%$ respectively as compare to reference beam, while the third model that strengthened by high strength concrete was stiffer than other beams.
\end{abstract}

Keywords: Castellated Steel Beam; Solid Beam; Load Carrying Capacity; Deflection; Abaqus Software.

\section{Introduction}

Castellated steel beam is expanded beam manufacturing by expanding standard rolled sections in a method which produce a uniform shape of opening in the web. Castellated beams are light, strong, low-cost and simple to connect at construction place. The holes on the beam web are useful to extend pipes and wires and other services across beams holes. Using of castellated beams give large design and building benefits. Open web beams have a high depth - to weight ratio, expanded section modulus, Sx and expanded strong - axis moment of inertia, Ix. These increments lead to increase spans length that is useful for wide span option by designers, increasing stiffness and strength of standard section, decreasing deflection compare with the original beams. Castellation proses produced beams with $50 \%$ deeper than the origin beam, enhanced the moment capacity up to $40 \%$ without adding steel and increasing load capacity with reducing beam weight [1].

* Corresponding author: dr.ahmadalshimmeri@coeng.uobaghdad.edu.iq

http://dx.doi.org/10.28991/cej-2019-03091339

(C) 2019 by the authors. Licensee C.E.J, Tehran, Iran. This article is an open access article distributed under the terms and conditions of the Creative Commons Attribution (CC-BY) license (http://creativecommons.org/licenses/by/4.0/). 


\subsection{Stiffness and Ductility Factor}

Stiffness is known as the load demanded to result unit deflection, while ductility is defined as a member ability to endure the inelastic deformations after yield deformation without large loss in its load carrying capacity. Ductility is effective parameter to be evaluated in structures design those exposed to different loading conditions. Flexural members' ductility can be evaluated from their load - deflection curves [2].

The ratio of the deflection at failure to the first yield deflection is defined as ductility factor $(\mu)$ as explained in the Equation 1:

$$
\mu=\frac{\Delta_{u}}{\Delta_{y}}
$$

Where:

$\Delta_{u}$ : Mid- span deflection at ultimate load.

$\Delta y=$ Mid-span deflection at first yield.[3]

\section{Manufacturing of Castellated Beam}

The castellated steel beams are fabricated by using Computer Numerical Control (CNC) to make a zigzag shape along the web of a wide - flange steel I- section and dividing into two symmetrical halves and then both parts are moved and reconnected by welding as shown in Figure 1 [4].

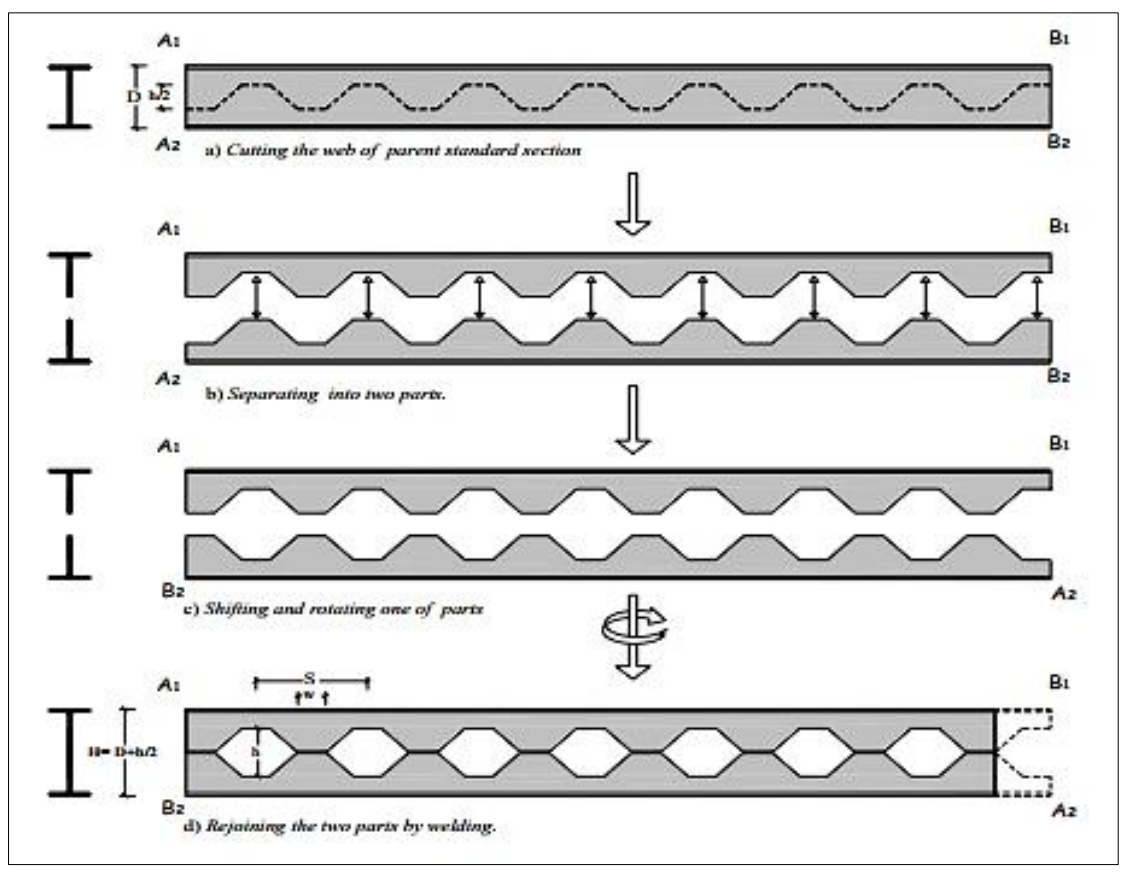

Figure 1. Manufacturing process of a castellated beam [4]

\section{Literature Review}

Ismail et al. (2014) studied the influence of different parameters (cross-section dimensions, length of beam, using of stiffeners, concrete strength, steel strength and concrete slab dimension) on both ultimate behavior of composite castellated steel beam and buckling load. ABAQUS program was used. It is found loading capacity of the composite castellated steel beam was raised by using vertical stiffeners, also it is noted when steel and concrete strength increase, the ultimate load and ductility increase and when concrete slab thickness increase, ultimate load also increase [5].

Budi et al. (2016) studied the effect of size and distance of castellated steel beams with hexagonal web openings. The comparison study of castellated steel beams was carried out using finite element method (FEM). The results of comparison analysis are then achieved by laboratory test of castellated steel beam specimens having $225 \mathrm{~mm}$ height. Six specimens were fabricated from IWF section with various hole angle of $45^{\circ}, 50^{\circ}, 55^{\circ}, 60^{\circ}, 65^{\circ}$ and $70^{\circ}$. All models have vertical height holes (ho) of $150 \mathrm{~mm}$ and the distance between holes change from 0.052 ho to 3.15 ho. All beams having a clear span of $3000 \mathrm{~mm}$ with simple supports and two concentrated load system. Root beam section used was IWF $150 \times 75 \times 5 \times 7 \mathrm{~mm}$ which produced a castellated beam of size $225 \times 75 \times 5 \times 7 \mathrm{~mm}$. The analysis of results show that the capacity of specimens increases by 1.938 to 2.041 as compare to the original section. The best results from FEM 
analysis was a specimen with $60^{\circ}$ angle and the distance between holes was 0.186 ho to 0.266 ho. Comparison between FEM analysis and laboratory test show good agreement between them [6].

Satyarno et al. (2017) investigated flexural, shear strength and load carrying capacity for castellated steel beams with total depth rectangular hole with partial encased reinforcement concrete. Two groups of beams were used, one beam with long span and two beams with short span to study flexural and shear strength respectively. All beams have simple supports and subjected to two equal concentrated loads at mid third of span. Results show that load carrying capacity at yield of castellated steel beams without encased reinforcement concrete for long and short span was similar under the effect of vierendeel truss mechanism. For castellated steel beams encased partially with reinforcement concrete, flexural failure was identical for long and short span beams while the beams with short span not arrived moment failure because of shear failure happened firstly, while for shear strength, beams with sort span, the shear failure was occurred at diagonal struts in the concrete through the web holes. It was concluded that is vierendeel truss failure can prevent by using partial encased reinforcement concrete for castellated beams and flexural strength increased (3.5) times compared with origin section [7].

Richard et al. (2017) performed numerical study to investigate the behavior of composite castellated steel beam subjected to monotonic loading with two-point load and simple support conditions and compare the results with solid and composite solid beam (without castellation). Hot rolled steel (HRS) I- section was used to fabricate the castellated beam that have expanded section depth of 306.6 and $3800 \mathrm{~mm}$ clear span length, while the reinforced concrete slab for composite sections have $665 \mathrm{~mm}$ width and $150 \mathrm{~mm}$ depth. All beams were simulated using ABAQUS program. The results show that the load carrying capacity of the composite castellated beam enhanced to (6.24) times than the load carrying capacity of the solid origin I-beam and (1.2) times compared the composite solid beam [8].

Samadhan et al. (2018) carried out analytical study to compare the loads carrying capacity of castellated and solid steel beams. Steel I- section of ISMB 200 with simple support conditions exposed to one central load at midspan has been adopted. Castellation ratio is adopting as 1.5, 1.6 and 1.8. Finite element analysis was performed using ANSYS version 12. It was noted from results that the minimum hole height must not be less than $50 \%$ depth of the section, maximum hole depth must not be greater than $75 \%$ depth of the section also it was noted that the best expansion ratio was 1.5 [9].

Sahar et al. (2019) studied the influence of web holes on the vertical deflection of castellated steel beams using theoretical analysis that is based on potential energy method and numerically by ANSYS software and estimate the deflection resulted from shear for castellated steel beams with various span lengths and flange breadths exposed to uniform distributed load. The results show that shear influence on the deflection of castellated steel beam have significant effect specially for medium and short beams, also its noted that the influence of web shear on the deflection decreased when castellated steel beam length raises, however it was seen that the deferent between analytical and numerical approach was not surpass $6 \%$ for short beam length having narrow or wide sections [10].

\section{Mode of Failure of Castellated Steel Beams}

The design approach of castellated steel beams deepened on a typical limits states but the existence of web holes and welding lead to more mode of failures. For safe castellated steel beam design, the next limit states must be checked:

- Flexural failure mechanism.

- Rupture of welded joints.

- Vierendeel bending for tee sections.

- Buckling of web post due to shear force.

- Compression web-post buckling.

- Lateral torsional buckling.

These mode of failures are widely related to castellated steel beam geometry, parameters shape, loading type and providing of lateral supports [11].

The design of castellated steel beam requires calculating global forces (shear and bending moment) at every hole and web- post result from applied loads, these global forces used to find local forces at upper and lower tees, web posts and gross section, then the failure of web -posts and tees will be checked under local forces. The mode of failure related to castellated steel beams are shown in Figure 2 [1]. 


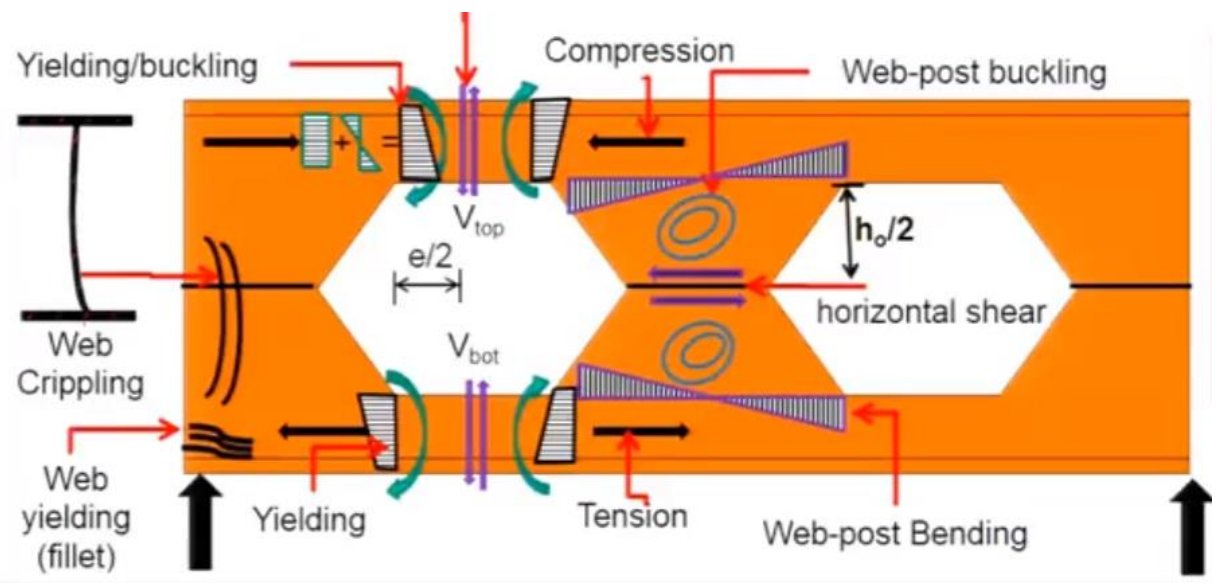

Figure 2. Mode of failure of castellated steel beams [1]

\section{Terminology of castellated Steel Beam}

Various expressions are used to define the castellated steel beam components as illustrated below:

- Throat Depth: is the web part height between flanges and tee sections.

- Web post: is the solid part cross section of castellated steel beam.

- Throat Width: is a horizontal cutting on parent steel beam.

- Top Tee: Higher part of the beam up of dropping of the throat width.

- Bottom Tee: Down part of the beam under the dropping of the throat width.

- Expansion ratio: Ratio of the increase in depth of the parent beam section to the depth of the castellated section.

All castellated steel beams components are shown in Figure 3 [12].

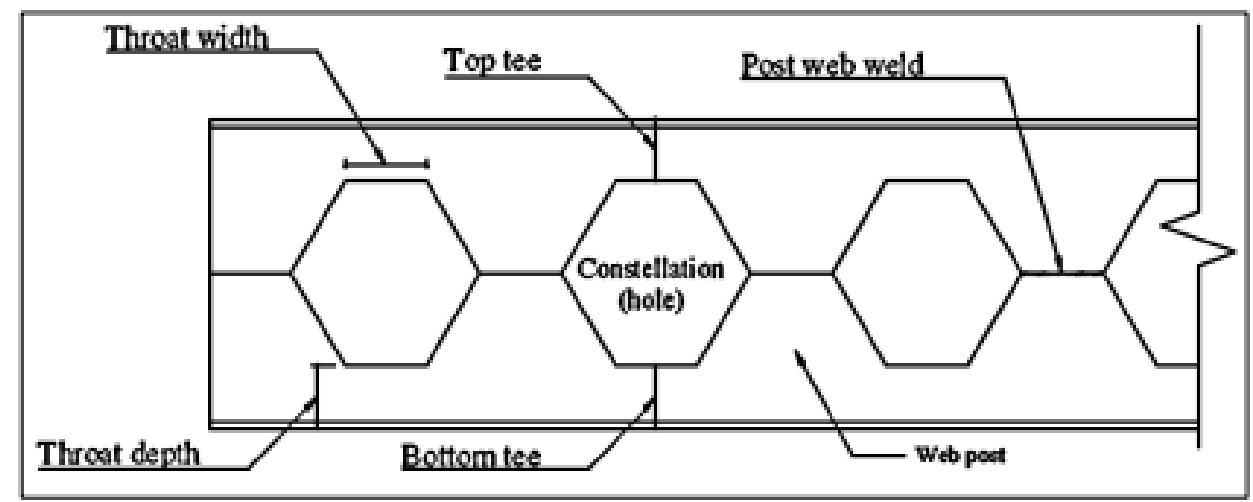

Figure 3. Castellated steel beam components [12]

Limitations of dimensions for castellated steel beam components are illustrated in Figure 4 [13].

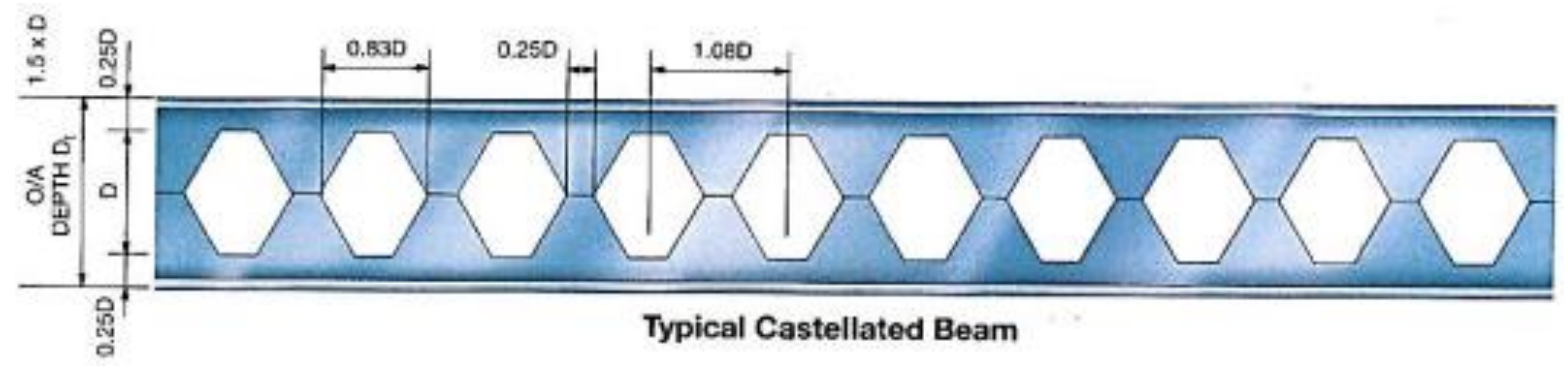

Figure 4. Castellated steel beam components limits [13] 


\section{Investigated Beams Details and Materials Properties}

In order to investigate the effect of castellation process with and without strengthening on the ultimate strength and deflection and compare the results with parent beam, four models are adopted having deferent dimension and properties as following:

- First model: Solid steel beam (SB), represent the reference specimen with IPE 200 rolled standard section, its measurements are shown in Table 1.

- Second model: Unconfined castellated steel beam (CB1), represent castellated steel beam with hexagonal holes without strengthening. Its measurements are shown in Table 2.

- Third Model: Castellated steel beam(CB2), It is a specimen have a (web and flange) confined by high strength concrete only with $(29 \mathrm{~mm})$ depth for each side, its measurements are shown in Table 2

- Fourth model: Castellated steel beam(CB3), It is a specimen with (web and flange) confine by high strength concrete with $(29 \mathrm{~mm})$ depth for each side and $(\varnothing 6 \mathrm{~mm})$ laced reinforced which are used inclined continuous reinforcement of two layers on each side of the castellated steel beam web. The inclination angle of lacing reinforcement with respect to the longitudinal axis is $45^{\circ}$,its measurements are shown in Table 2 , while castellated steel beam parameters are shown in Figure 5.

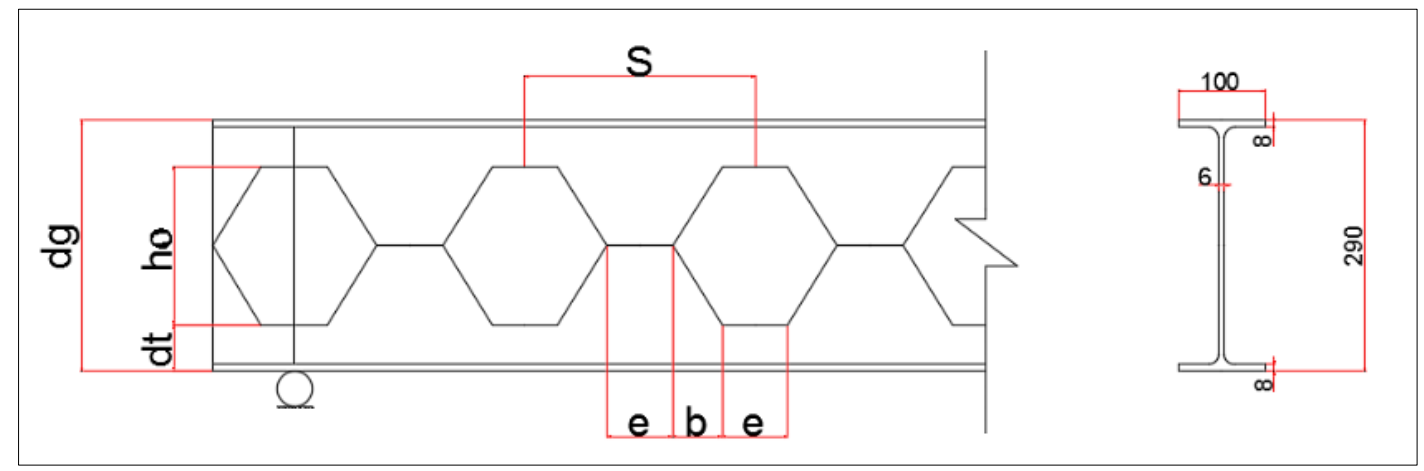

Figure 5. Castellated steel beam parameters (Dimensions in $\mathbf{m m}$ )

Table 1. Origin IPE200 section measurements

\begin{tabular}{ccccccccccc}
\hline Section & $\begin{array}{c}\mathbf{G} \\
(\mathbf{k g} / \mathbf{m})\end{array}$ & $\begin{array}{c}\mathbf{h} \\
(\mathbf{m m})\end{array}$ & $\begin{array}{c}\mathbf{B} \\
(\mathbf{m m})\end{array}$ & $\begin{array}{c}\boldsymbol{t}_{\boldsymbol{w}} \\
(\mathbf{m m})\end{array}$ & $\begin{array}{c}\boldsymbol{t}_{\boldsymbol{f}} \\
(\mathbf{m m})\end{array}$ & $\begin{array}{c}\mathbf{r} \\
(\mathbf{m m})\end{array}$ & $\begin{array}{c}\mathbf{A} \\
\left(\mathbf{m m}^{2}\right)\end{array}$ & $\begin{array}{c}\boldsymbol{I}_{x} \\
\mathbf{1 0}^{4}\left(\mathbf{m m}^{\mathbf{4}}\right)\end{array}$ & $\begin{array}{c}\boldsymbol{Z}_{\boldsymbol{x}} \\
\mathbf{1 0}^{\mathbf{3}}\left(\mathbf{m m}^{\mathbf{3}}\right)\end{array}$ & $\begin{array}{c}\boldsymbol{S}_{\boldsymbol{x}} \\
\mathbf{1 0}^{\mathbf{3}}\left(\mathbf{m m}^{\mathbf{3}}\right)\end{array}$ \\
\hline IPE200 & 22.4 & 200 & 100 & 6 & 8 & 12 & 2850 & 1943 & 220.6 & 194.3 \\
\hline
\end{tabular}

Table 2. Investigated castellated steel beam measurements

\begin{tabular}{cccccccc}
\hline \multirow{2}{*}{ Specimen } & \multicolumn{8}{c}{ Section parameters } \\
\cline { 2 - 8 } & e & b & d & $\boldsymbol{t}_{\boldsymbol{w}}$ & $\boldsymbol{t}_{\boldsymbol{f}}$ & $\mathbf{s}$ & $\boldsymbol{h}_{\circ}$ \\
\hline $\mathrm{CB} 1, \mathrm{CB} 2 \& \mathrm{CB} 3$ & 76 & 57 & 300 & 6 & 8 & 266 & 183 \\
\hline
\end{tabular}

Where:

$\mathrm{d}=$ Total beam depth $(\mathrm{mm})$

$\mathrm{S}=$ Center to center distance between holes $(\mathrm{mm})$

$\mathrm{b}=$ Flange width $(\mathrm{mm})$

$t_{w}=$ Web thickness (mm)

$\mathrm{A}=$ Section area $\left(\mathrm{mm}^{2}\right)$

$I_{x}=$ Moment of inertia about $\mathrm{x}$-axis $\left(\mathrm{mm}^{4}\right)$

$Z_{x}=$ Plastic section modulus $\left(\mathrm{mm}^{3}\right)$ $h_{\circ}=$ Hole depth $(\mathrm{mm})$

$\mathrm{e}=$ Distance between holes $(\mathrm{mm})$

$t_{f}=$ Flange thickness $(\mathrm{mm})$

$\mathrm{G}=$ Section weight $(\mathrm{Kg} / \mathrm{m})$

$\mathrm{B}=$ Flange width $(\mathrm{mm})$

$S_{Z}=$ Elastic section modulus $\left(\mathrm{mm}^{3}\right)$ 
The mechanical properties of steel and concrete materials are listed in Table 3.

Table 3. Material properties

\begin{tabular}{cccc}
\hline Material & Strength MPa & Modulus of Elasticity (MPa) & Poisson' s ratio \\
\hline Concrete & $f_{c}^{\prime}=67$ & 38717 & 0.2 \\
Steel beam & $f_{y}=360$ & 210000 & 0.3 \\
Reinforcement bars & $f_{y}=443$ & 200000 & 0.3 \\
\hline
\end{tabular}

All specimens have a clear span of $(3192 \mathrm{~mm})$ subjected to two equal concentrated load at mid third of the beam with simple support condition, the specimen configuration and their sections adopt in this study are illustrated in Figure 6.

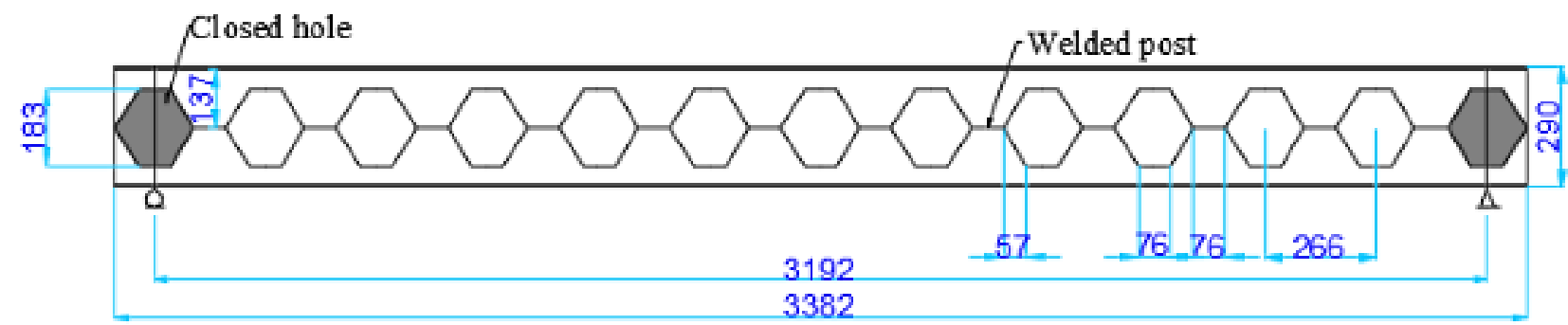

a-(CB1): Castellated steel beam without strengthening (reference specimen)

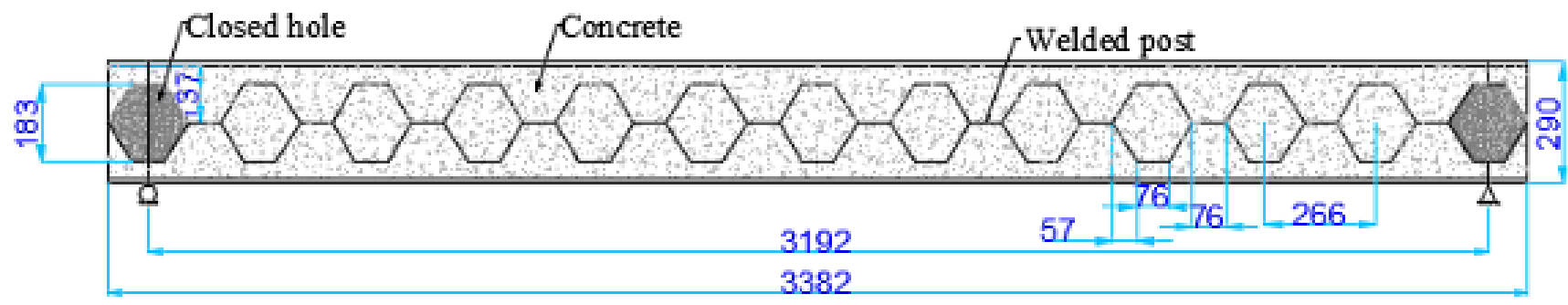

b-(CB2): Castellated steel beam confined with high strength concrete

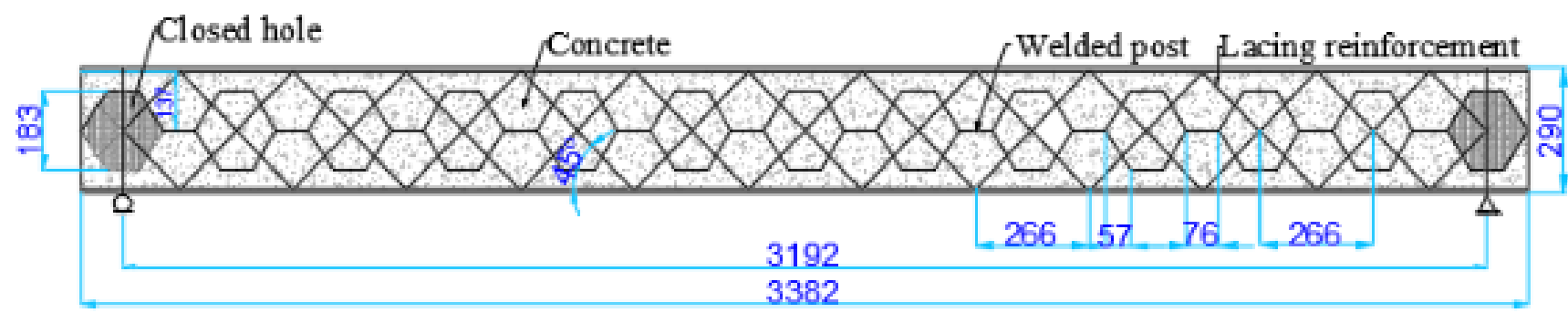

c-(CB3): Castellated steel beam confined with high strength concrete and laced reinforcement

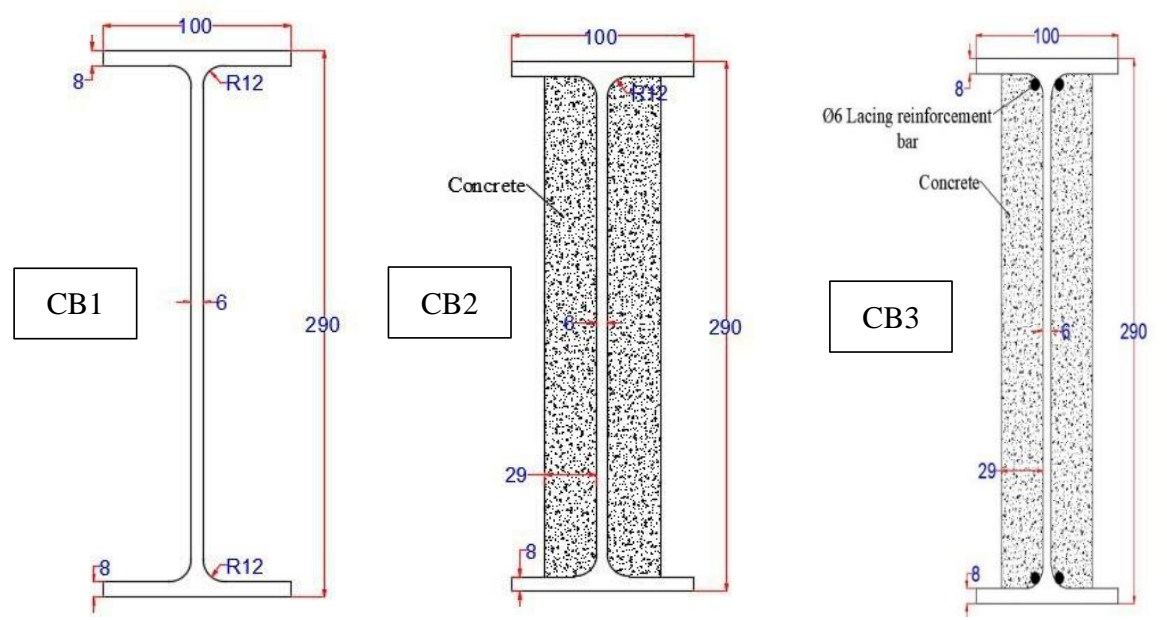

Figure 6. Dimension Details of Castellated Steel Beams and Sections (All Dimensions in mm) 


\section{Finite Element Modeling and Results}

\subsection{Finite Element Modeling}

In this paper, the numerical modeling was carried out by using finite element software (Abaqus, ver.6.14.5), in which static analysis was performed to calculate the ultimate strength and maximum deflection at mid- span for analyzed solid and castellated beams subjected to two-point load with simple support conditions. A continuum 3D eight-node hexahedron solid elements (C3D8R) with reduced integration are used to model castellated steel beam and concrete .These elements were adequate for modelling general three dimensional solid structures [14]. While two node linear 3D truss elements (T3D2), were used to simulate laced reinforcement. For the steel castellated beams and concrete interface, (Tie interaction) was used so the steel beam surface was considered as the master surface and the concrete surface as the slave surface, while for interfacing between lacing reinforcement and concrete embedded interaction was used. The size of mesh was selected as a $25 \mathrm{~mm}$ for solid steel beam, $30 \mathrm{~mm}$ for castellated beam, $20 \mathrm{~mm}$ for concrete and 200 $\mathrm{mm}$ for lacing reinforcement bars. The finite element models considered both materials geometric and nonlinearity. The mechanical properties of materials were taken as mention in Table 3. The deflected shape for all analyzed specimens are shown in Figure 7.

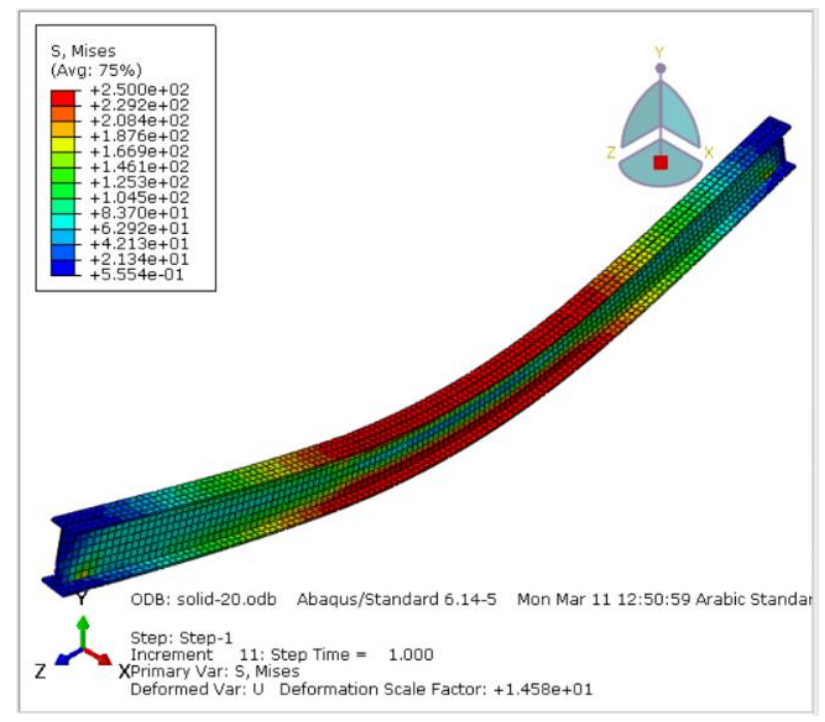

(a) SB

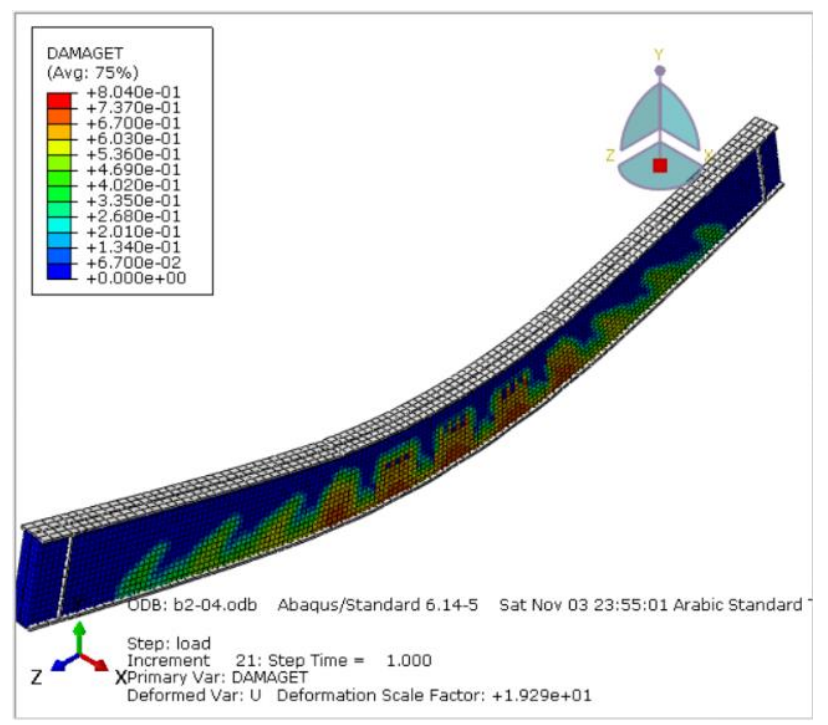

(c) $\mathrm{CB} 2$

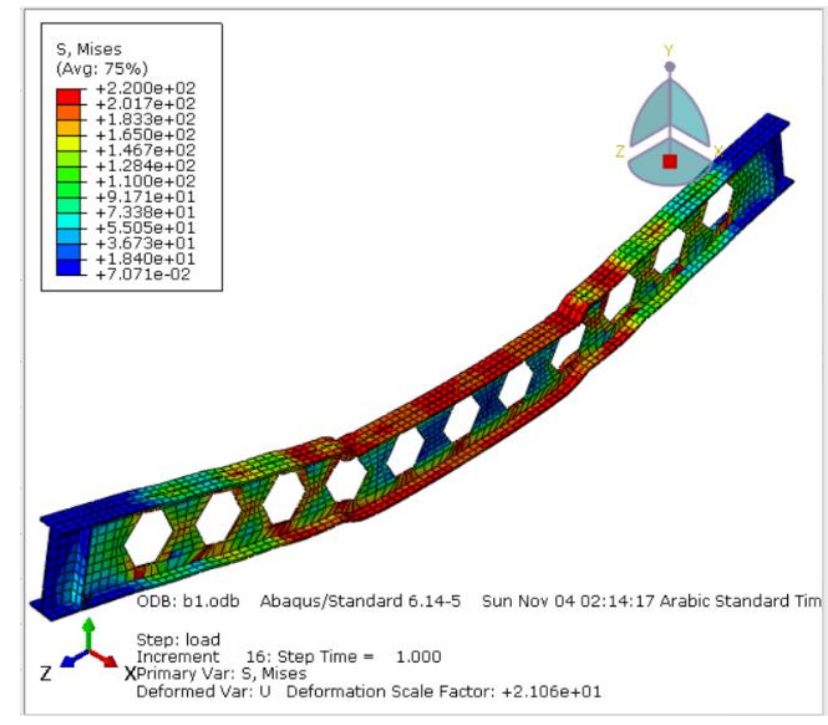

(b) CB1

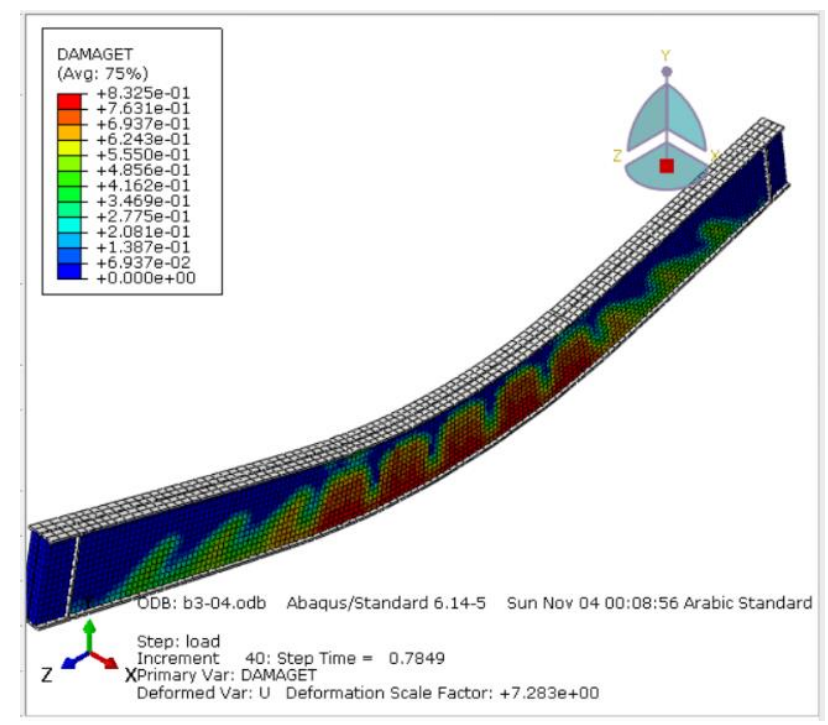

(d) CB3

Figure 7. Deflected shapes for analyzed beams 


\subsection{Finite Element Results and Discussion}

\subsubsection{Load Carrying Capacity and Deflection Results}

The results of maximum deflection at mid span and corresponding load carrying capacities at both service and failure stage and comparison with respect to solid beam values for all analyzed beams obtained from Abaqus software were listed in table 4 and load- deflection curves are shown in Figure 8, while the comparison between load carrying capacity values for all beams were shown in Figure 9.

Table 4. Load carrying capacity and mid span deflection values for all analyzed beams

\begin{tabular}{ccccccc}
\hline $\begin{array}{c}\text { Specimen } \\
\text { Number }\end{array}$ & $\begin{array}{c}\boldsymbol{P}_{\text {service }} \\
(\mathbf{K N})\end{array}$ & $\begin{array}{c}\boldsymbol{P}_{\boldsymbol{u}} \\
(\mathbf{K N})\end{array}$ & $\begin{array}{c}\Delta_{\text {total at }} \boldsymbol{P}_{\boldsymbol{u}} \\
(\mathbf{m m})\end{array}$ & $\begin{array}{c}\Delta_{\text {at }} \boldsymbol{P}_{\text {service }} \\
(\mathbf{m m})\end{array}$ & $\frac{\Delta_{a t} \boldsymbol{P}_{\text {service }}-\Delta_{S B}}{\Delta_{\text {SB }}} \times \mathbf{1 0 0 \%}$ & $\frac{\boldsymbol{P}_{\boldsymbol{u}}-\boldsymbol{P}_{\boldsymbol{u} \text { solid }}}{\boldsymbol{P}_{\boldsymbol{u} \text { solid }}} \times \mathbf{1 0 0} \%$ \\
\hline $\mathrm{SB}$ & 52.5 & 75 & 23 & 11 & $\ldots \ldots$. & $\ldots \ldots$ \\
$\mathrm{CB} 1$ & 73.03 & 104.33 & 16 & 7 & 36.36 & 39.11 \\
$\mathrm{CB} 2$ & 108.12 & 154.46 & 17.39 & 10 & 9.10 & 105.95 \\
$\mathrm{CB} 3$ & 118.01 & 168.58 & 58 & 8 & 27.27 & 124.77 \\
\hline
\end{tabular}

Where:

$P_{u}=$ Ultimate load

$\Delta_{\text {total at }} P_{u}=$ Total mid-span deflection at ultimate load $\Delta_{S B}=$ Deflection of origin solid beam at service load
$P_{\text {service }}=$ Load at service limit that is supposed as a $70 \%$ of the ultimate load value

$\Delta_{a t} P_{\text {service }}=$ Mid-span deflection at service load

$P_{u \text { solid }}=$ Ultimate load of origin solid beam

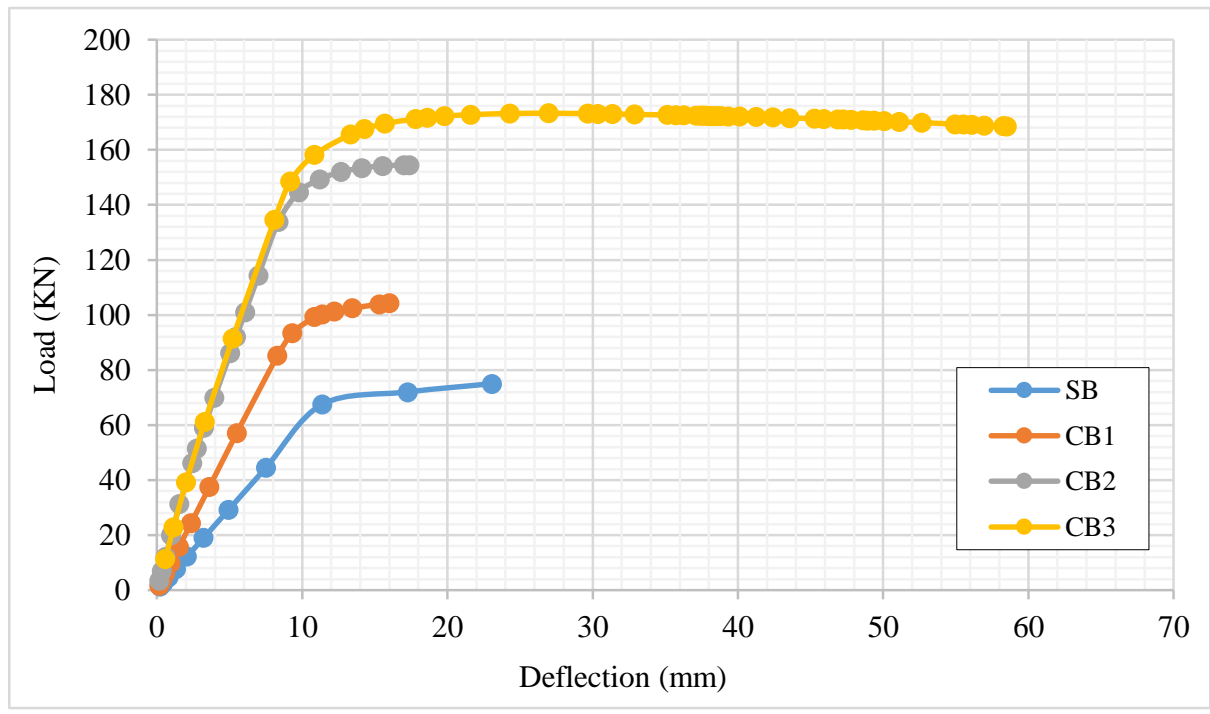

Figure 8. Load- deflection curves for all analyzed beams

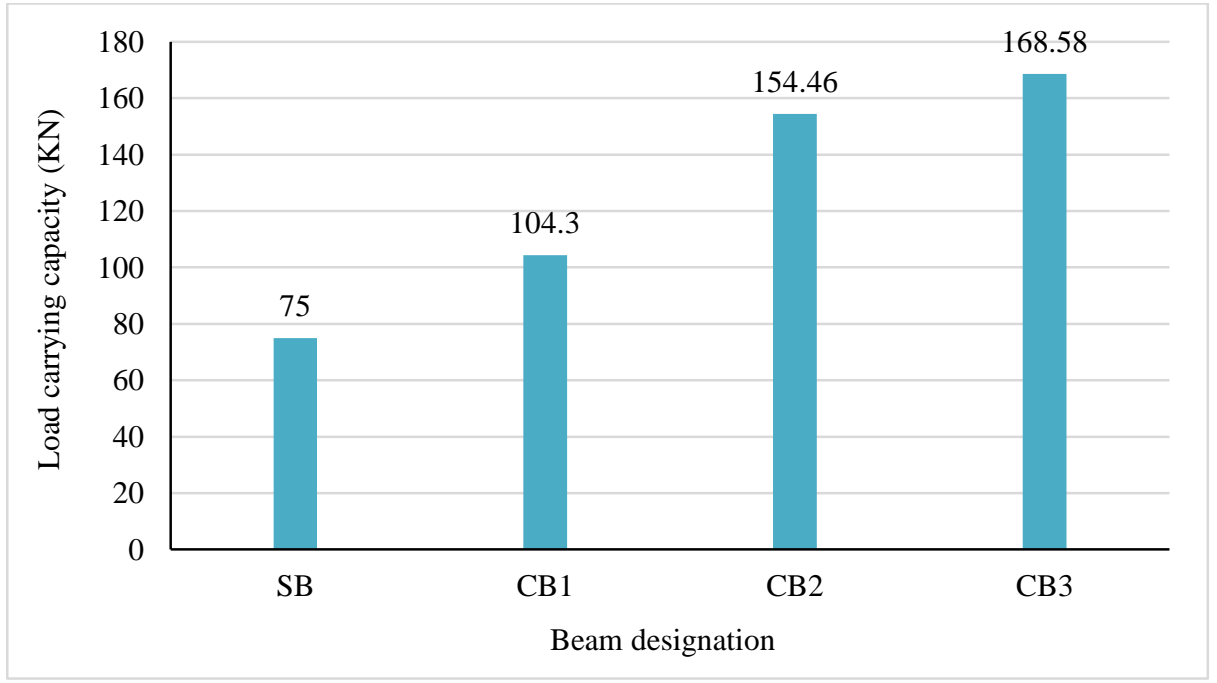

Figure 9. Load carrying capacity values for all analyzed beams 
Noting that service load values are considered as a $70 \%$ of ultimate load values for all analyzed beams.

The results show that the load carrying capacity values of castellated steel beams (CB1, CB2 and CB3) were increased by $39.11,105.95$ and $124.77 \%$ respectively compared with origin solid beam (SB) due to increase beams section depth and rigidity after castellation and strengthening process, while mid-span deflection values at service load were decreased by $36.36,9.10$ and $27.27 \%$ respectively comparing with the origin solid steel beam due to increasing section dimensions and stiffness after castellation process and using strengthening technique respectively. Noting that there was significant increasing in total mid-span deflection at ultimate load for CB3 compare with solid beam (SB) due to increase beam ductility of flexural element after using lacing reinforcement bars.

\subsubsection{Stiffness}

Stiffness values were calculated from deflection and ultimate load values obtained from finite element analysis. Results show that the maximum stiffness value was noted in specimen CB2 due to increasing section dimension and rigidity after castellation and strengthening process respectively. Stiffness values are shown in Table 5 and Figure 10.

Table 5. Stiffness of analysed beams

\begin{tabular}{ccccc}
\hline $\begin{array}{c}\text { Specimen } \\
\text { designation }\end{array}$ & $\begin{array}{c}\text { Ultimate load } \boldsymbol{P}_{\boldsymbol{u}} \\
(\mathbf{K N})\end{array}$ & $\begin{array}{c}\text { Ultimate deflection } \\
\boldsymbol{\Delta}_{\boldsymbol{u}}(\mathbf{m m})\end{array}$ & $\begin{array}{c}\text { Stiffness= } \\
(\mathbf{K N} / \mathbf{m})\end{array}$ & $\begin{array}{c}\text { Difference in } \\
\text { stiffness } \%\end{array}$ \\
\hline SB & 75 & 23 & 3.26 & - \\
CB1 & 104.33 & 16 & 6.52 & 100 \\
CB2 & 154.46 & 17.39 & 8.88 & 172.39 \\
CB3 & 168.58 & 58 & 2.91 & 10.74 \\
\hline
\end{tabular}

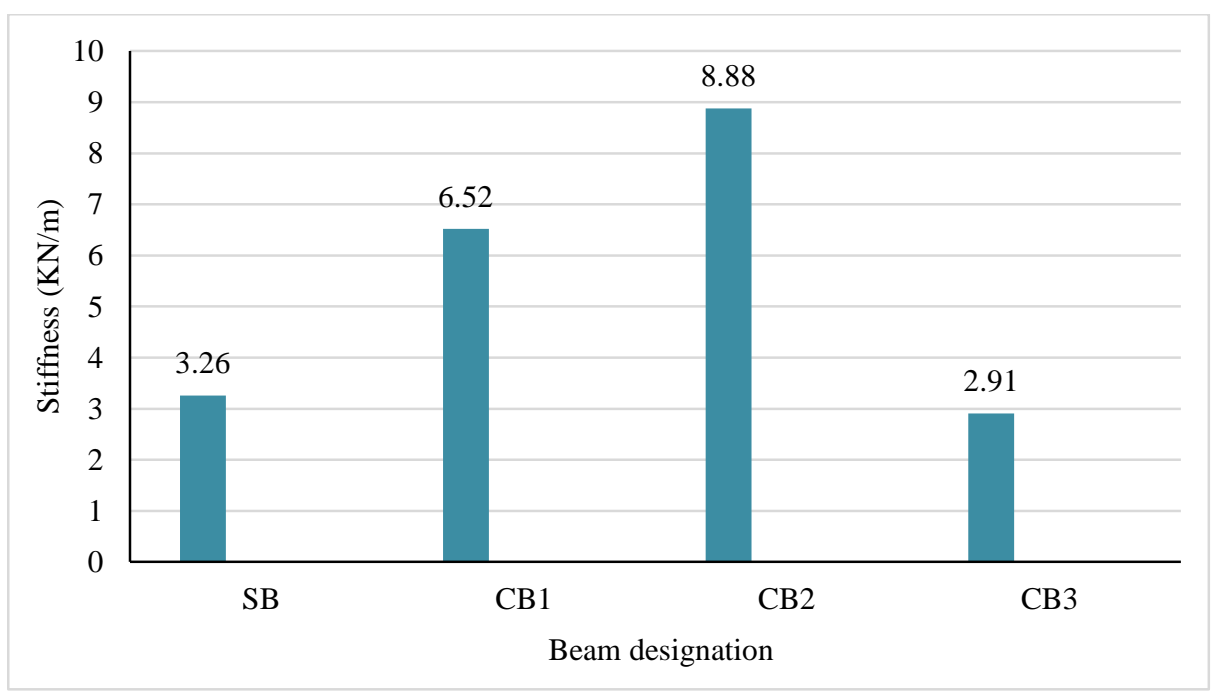

Figure 10. Stiffness values for analyzed beams

\subsubsection{Ductility Characteristics}

Table 6 and Figure 11 show the ductility factor results calculated from mid span deflection values at yield and ultimate loading stage obtained from finite element analysis. The result show the ductility factor decreased by $26.09 \%$ and $5.65 \%$ for CB1 and CB2 respectively while ductility factor was increased by $165.65 \%$ for CB3 as compared to reference beam SB, this enhancement related to using of laced reinforcement that causing significant increasing in flexural element.

Table 6. Ductility factor of analyzed beams

\begin{tabular}{ccccccc}
\hline $\begin{array}{c}\text { Specimen } \\
\text { designation }\end{array}$ & $\begin{array}{c}\text { Ultimate } \\
\text { Load }(\mathbf{K N})\end{array}$ & $\begin{array}{c}\text { Deflection at } \\
\text { ultimate load (mm) }\end{array}$ & $\begin{array}{c}\text { Load at } \\
\text { Yield (KN) }\end{array}$ & $\begin{array}{c}\text { Deflection at yield } \\
\text { load (mm) }\end{array}$ & $\begin{array}{c}\text { Ductility } \\
\text { factor }\end{array}$ & $\begin{array}{c}\text { Difference } \\
\text { In ductility \% }\end{array}$ \\
\hline SB & 75 & 23 & 60 & 10 & 2.3 & - \\
CB1 & 104.33 & 16 & 95 & 9 & 1.7 & 26.09 \\
CB2 & 154.46 & 17.39 & 136 & 8 & 2.17 & 5.65 \\
CB3 & 168.58 & 58 & 157 & 9.5 & 6.11 & 165.65 \\
\hline
\end{tabular}




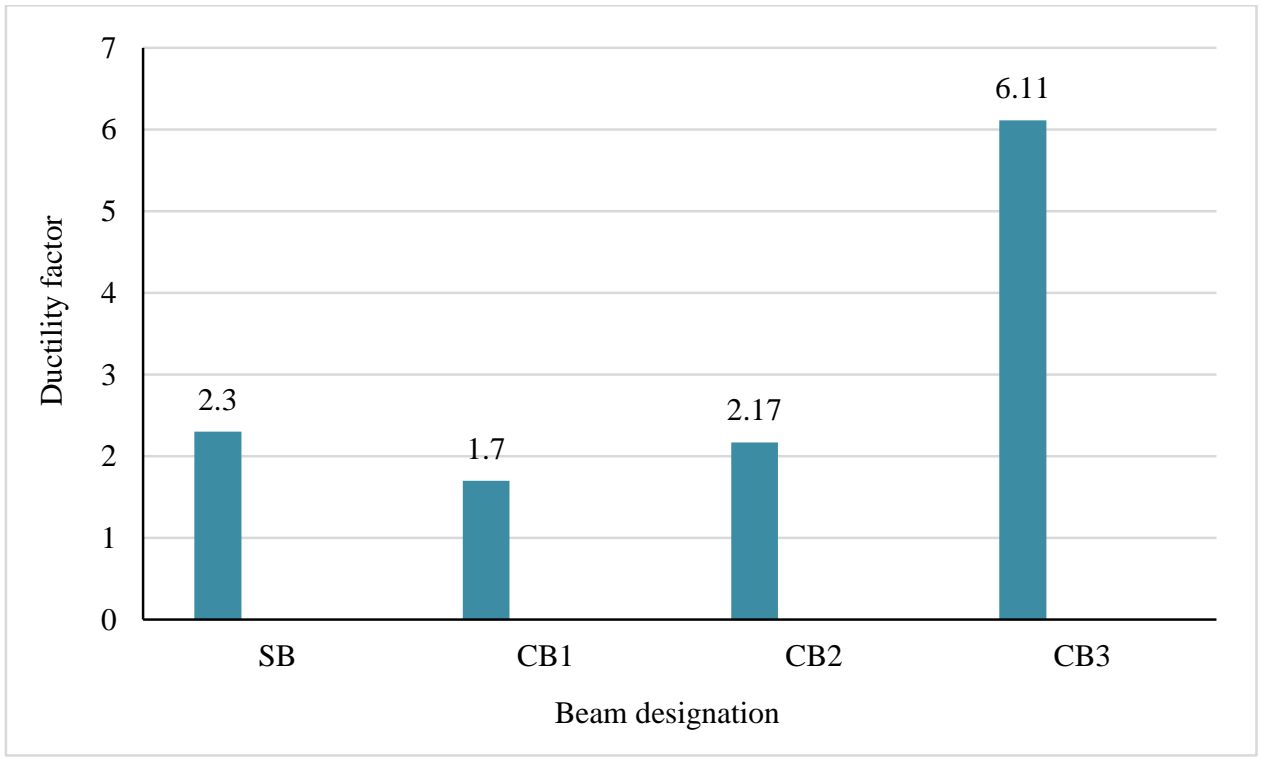

Figure 11. Ductility factor values for analyzed beams

\subsubsection{Ultimate Moment Results}

Flexural capacity values are shown in Table 7 and Figure 12, the results show that the ultimate moment values increase by $39.09,105.49$ and $124.79 \%$ for CB1, CB2 and CB3 respectively as compare to reference beam SB. This enhancement related to increasing in section stiffness and strength after castellation and strengthening proses.

Table 7. Ultimate moment of analyzed beams

\begin{tabular}{ccccc}
\hline $\begin{array}{c}\text { Specimen } \\
\text { designation }\end{array}$ & $\begin{array}{c}\text { Ultimate load } \boldsymbol{P}_{\boldsymbol{u}} \\
(\mathbf{K N})\end{array}$ & $\begin{array}{c}\text { Ultimate moment } \\
\boldsymbol{M}_{\boldsymbol{u}}(\mathbf{K N} / \mathbf{m})\end{array}$ & $\frac{\boldsymbol{M}_{\boldsymbol{u}}}{\boldsymbol{M}_{\boldsymbol{u} \text { ref. }}} \%$ & $\begin{array}{c}\text { Increasing in } \\
\boldsymbol{M}_{\boldsymbol{u}} \%\end{array}$ \\
\hline $\mathrm{SB}$ & 75 & 39.9 & 100 & - \\
$\mathrm{CB} 1$ & 104.33 & 55.5 & 139.09 & 39.09 \\
$\mathrm{CB} 2$ & 154.46 & 82.17 & 205.94 & 105.49 \\
$\mathrm{CB} 3$ & 168.58 & 89.69 & 224.79 & 124.79 \\
\hline
\end{tabular}

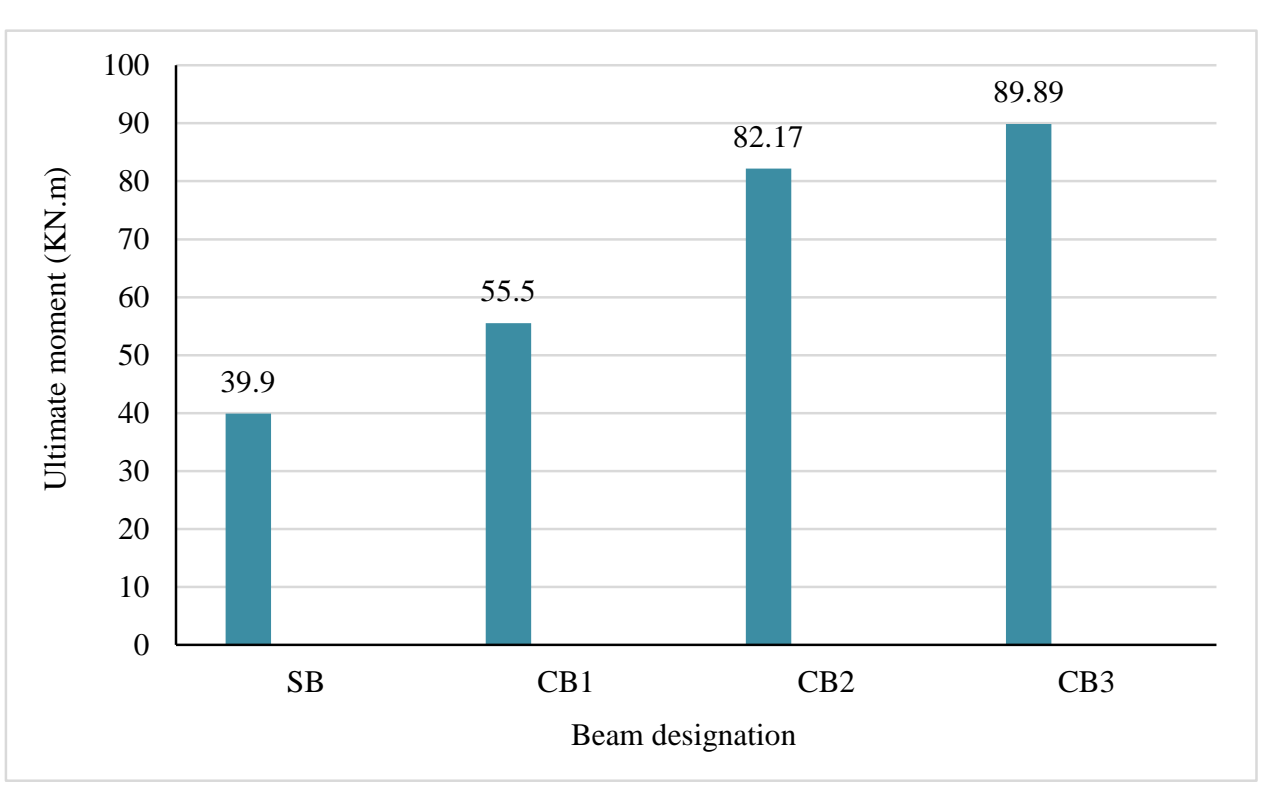

Figure 12. Ultimate moment values for analyzed beams 


\section{Conclusions}

Based on the numerical results obtained from Abaqus program the following conclusion were noted:

- For unconfined castellated steel beam, it was noted that the load carrying capacity was increased by $39.11 \%$ and mid-span deflection at service load was decrease by $36.36 \%$ as compared with origin solid steel beam.

- For castellated steel beam strengthened by high strength concrete it was noted that the load carrying capacity was increased by $105.95 \%$ and mid-span deflection at service load was decrease by $9.10 \%$ as compared with origin solid steel beam.

- For castellated steel beam strengthened by high strength concrete and lacing reinforcement it was noted that the load carrying capacity was increased by $124.77 \%$ and mid-span deflection at service load was decrease by $27.27 \%$ as compared with origin solid steel beam.

- Maximum ultimate moment and ductility were observed in the fourth model that strengthened by high strength concrete and lacing reinforcement so they increase by $124.79 \%$ and $165.65 \%$ respectively as compare to reference beam, while the third model that strengthened by high strength concrete was stiffer than other beams.

\section{Acknowledgement}

The authors wish to thank the University of Baghdad/Iraq for the financial support to complete this research and for the help and support submitted by the Civil Engineering Department.

\section{Conflicts of Interest}

The authors declare no conflict of interest.

\section{References}

[1] American Institute of steel construction, Inc. (AISC). "Castellated and cellular Beam Design”, Steel Design Guide-31, 14th Edition, 2016.

[2] Ahmad, Samer, Adnan Masri, and Zaher Abou Saleh. "Analytical and Experimental Investigation on the Flexural Behavior of Partially Encased Composite Beams.” Alexandria Engineering Journal 57, no. 3 (September 2018): $1693-1712$. doi:10.1016/j.aej.2017.03.035.

[3] Hallawi, Ali Faiq, and Ali Hussein Ali Al-Ahmed. "Enhancing the Behavior of One-Way Reinforced Concrete Slabs by Using Laced Reinforcement.” Civil Engineering Journal 5, no. 3 (March 19, 2019): 718. doi:10.28991/cej-2019-03091282.

[4] Hayder w. AL-Thabhawee, "Experimental Study of Effect of Hexagonal Holes Dimensions on Ultimate Strength of castellated Steel Beam”, Kufa Journal of Engineering. Vol. 8. No. 1, January 2017, p.p. 97-107.

[5] E.S. Ismail, R., A.S. Fahmy, and N. M. Tawfik. "Ultimate Behavior of Composite Castellated Beams under Vertical Loads." International Journal of Computer Applications 108, no. 5 (December 18, 2014): 40-46. doi:10.5120/18911-0214.

[6] Budi, Listiyono, Sukamta, and Windu Partono. "Optimization Analysis of Size and Distance of Hexagonal Hole in Castellated Steel Beams.” Procedia Engineering 171 (2017): 1092-1099. doi: 10.1016/j.proeng.2017.01.465.

[7] Satyarno, Iman, Djoko Sulistyo, Dina Heldita, and A. Talodaci Corte Real De Oliviera. "Full Height Rectangular Opening Castellated Steel Beam Partially Encased in Reinforced Mortar." Procedia Engineering 171 (2017): 176-184. doi: 10.1016/j.proeng.2017.01.324.

[8] Frans, Richard, Herman Parung, Achmad Bakri Muhiddin, and Rita Irmawaty. "Finite Element Modelling of Composite Castellated Beam.” Edited by J.-W. Park, H. Ay Lie, H. Hardjasaputra, and P. Thayaalan. MATEC Web of Conferences 138 (2017): 02009. doi:10.1051/matecconf/201713802009.

[9] Morkhade, Samadhan G., Subhan Shaikh, Ajay Kumbhar, Abdulaziz Shaikh, and Rushikesh Tiwari. "Comparative study of ultimate load for castellated and plain webbed beam." International Journal of Civil Engineering and Technology 9, no. 8 (2018): $1466-1476$.

[10] Elaiwi, Sahar, Boksun Kim, and Long-Yuan Li. "Bending Analysis of Castellated Beams.” Athens Journal of Technology \& Engineering 6, no. 1 (February 25, 2019): 1-16. doi:10.30958/ajte.6-1-1.

[11] Kaveh, A., and F. Shokohi. "Application of Grey Wolf Optimizer in design of castellated beams." (2016): 683-700.

[12] Boyed J. P. “Castellated Beam-New Development”, AISC National Engineering Conference, AISC Engineering Journal, Vol. 3, pp. 106-108, 1964.

[13] Harper, C. S. "Design in Steel 4: Castellated \& cellular beams", Port Talbot: British Steel, (1994).

[14] Ellobody, Ehab. "Design Examples of Steel and Steel-Concrete Composite Bridges." Finite Element Analysis and Design of Steel and Steel-Concrete Composite Bridges (2014): 221-467. doi:10.1016/b978-0-12-417247-0.00004-1. 